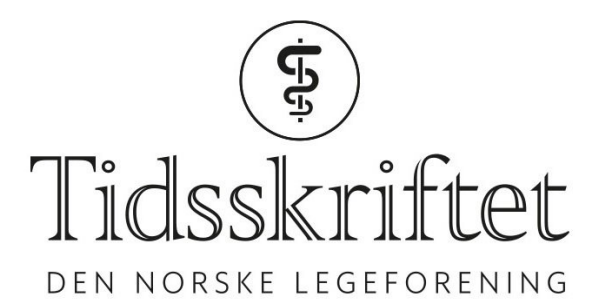

\title{
Glutenintoleranse uten cøliaki hos barn
}

DEBATT

CHANDRA SEKHAR DEVULAPALLI

E-post: chandev@gmail.com

Chandra Sekhar Devulapalli er dr.med., spesialist i barnesykdommer og rådgivende overlege i NAV arbeid og ytelser.

Forfatteren har fylt ut ICMJE-skjemaet og oppgir ingen interessekonflikter.

En økende andel av befolkningen unngår å spise gluten. Men om det er en tilstand der man ikke har cøliaki, men likevel ikke tåler gluten, er omdiskutert.

Glutenintoleranse uten cøliaki (non coeliac gluten sensitivity, NCGS) defineres som «et syndrom karakterisert av intestinale og ekstraintestinale symptomer relatert til inntak av glutenholdig mat hos personer som verken har cøliaki eller hveteallergi» (1). Symptomene kan ofte ligne på dem som finnes ved cøliaki, men det er ingen utslag på tester for cøliaki. Det er også betydelig symptomoverlapp mellom cøliaki og glutenintoleranse uten cøliaki. Det ser ikke ut som glutenintoleranse uten cøliaki har sterk familiær disposisjon, og det er ingen relasjon til alvorlig malabsorpsjon eller malignitet (2). Prevalensstudier på glutenintoleranse uten cøliaki er utfordrende grunnet mangelen på en spesifikk diagnosemarkør og en standardisert diagnostisk prosedyre. I en metaanalyse (3) ble det funnet 17 studier av glutenintoleranse uten cøliaki der prevalensen varierte betydelig, fra o,5\% til 13\%, mens prevalensen var 5,2 \% hos barn ved en spesialklinikk (4).

\section{Ukjente mekanismer}

Mekanismene bak glutenintoleranse uten cøliaki er ukjent. Hvorvidt det faktisk er gluten som skaper problemene denne pasientgruppen opplever, er omdiskutert (5). Termen glutenintoleranse uten cøliaki er også omdiskutert, da gluten trolig ikke er alene om utviklingen av symptomer (6). Per dags dato er det tre hovedhypoteser knyttet til hva som trigger symptomene denne pasientgruppen opplever: gluten, fruktaner i hvete og amylasetrypsin-inhibitorer (6). Gluten utgjør 80-90\% av proteininnholdet $\mathrm{i}$ hvete, mens amylasetrypsin-inhibitorer kun utgjør 2-4\%. Da gluten og amylase-trypsin-inhibitorer alltid opptrer sammen, vil en glutenfri diett også være en amylase-trypsin-inhibitorer-fri diett. Fruktaner er en type oligosakkarider som inngår i betegnelsen fermenterbare oligosakkarider, disakkarider, monosakkarider og polyoler, bedre kjent som FODMAP. Hvorvidt det er gluten alene eller hvete i sin helhet (både fruktanene og proteinene) som skaper en reaksjon, er foreløpig ukjent. Det er uenighet om glutenintoleranse uten cøliaki kan sies å være en egen diagnose eller om den faller innunder samlebetegnelsen irritabel tarmsyndrom (IBS) (6). Symptomene ligner hverandre. 


\section{Diagnostiske utfordringer}

Mangelen på en spesifikk diagnosemarkør for glutenintoleranse uten cøliaki og en standardisert diagnostisk prosedyre gjør diagnosen diffus og inkluderer pasienter med en rekke symptomer. Behovet for en standardisert diagnosemetode er nødvendig for å kunne identifisere og diagnostisere riktig gruppe pasienter (1). Ifølge pediatriveilederen (7) omtales glutenintoleranse uten cøliaki som en tilstand hos pasienter med klare intoleransesymptomer på glutenholdig kost, uten utslag i IgA-antitransglutaminase og/eller IgG-anti-deamidert gliadinpeptid (DGP). Ved histologi påvises ingen «flat» tottestruktur eller tegn til totteatrofi i tynntarmslimhinne i biopsi. Disse pasientene tilfredsstiller ikke kravene til diagnosen cøliaki, men må følges opp.

Dagens retningslinjer for diagnostisering av glutenintoleranse uten cøliaki anbefaler en dobbeltblind, placebokontrollert provokasjon med gluten som et kriterium for å stille en diagnose (1). Glutenprovokasjon skal gjennomføres etter en eliminasjonsfase der pasienten spiser glutenfritt. Pasienter som får tilbakefall av symptomer under glutenprovokasjon, får diagnosen glutenintoleranse uten cøliaki.

Mangelen på en spesifikk diagnosemarkør for glutenintoleranse uten cøliaki og en standardisert diagnostisk prosedyre gjør diagnosen diffus

\section{Først utredning, så diett}

Ut fra det vi vet i dag, er det ikke spesifikke biokjemiske, immunologiske eller histopatologiske markører assosiert med glutenintoleranse uten cøliaki (8). Grunnet manglende biomarkører bygger diagnosen i dag på eksklusjon av cøliaki og hveteallergi samt effekt av glutenfritt kosthold. Det er også en utfordring at en stor andel pasienter er selvdiagnostisert og har startet med et glutenfritt kosthold uten klinisk støtte eller veiledning. Tilstanden er ofte mistenkt av pasientene selv, da de opplever god effekt av glutenfritt kosthold. European Society for the Study of Coeliac Diseases retningslinjer anbefaler fullstendig utredning, inkludert duodenalbiopsi, for å utelukke cøliaki og hveteallergi mens pasienten er på glutenholdig diett (8).

Pasienter med glutenintoleranse uten cøliaki kan i Norge søke grunnstønad fra NAV (9). Pasientene anbefales et glutenfritt kosthold. Hvorvidt et strengt glutenfritt kosthold er nødvendig, hvorvidt tilstanden er kronisk og hvorvidt andre substanser enn gluten bør unngås, er foreløpig ukjent. Det er viktig å unngå at barn står på unødvendige eliminasjonsdietter over tid. Det er også viktig at fullstendig utredning er gjennomført for å utelukke cøliaki og hveteallergi mens pasienten er på glutenholdig diett før man vurderer diagnosen glutenintoleranse uten cøliaki. På bakgrunn av diagnostiske utfordringer bør utredningen hovedsakelig gjennomføres i spesialisthelsetjenesten.

LITTERATUR:

1. Catassi C, Elli L, Bonaz B et al. Diagnosis of Non-Celiac Gluten Sensitivity (NCGS): The Salerno Experts' Criteria. Nutrients 2015; 7: 4966-77. [PubMed][CrossRef]

2. Meijer CR, Shamir R, Mearin ML. Coeliac disease and noncoeliac gluten sensitivity. J Pediatr Gastroenterol Nutr 2015; 6o: 429-32. [PubMed][CrossRef]

3. Molina-Infante J, Santolaria S, Sanders DS et al. Systematic review: noncoeliac gluten sensitivity. Aliment Pharmacol Ther 2015; 41: 807-20. [PubMed][CrossRef]

4. Camhi SS, Sangal K, Kenyon V et al. Pediatric Nonceliac Gluten Sensitivity: A Gluten-related Disorder Treatment Center Experience. J Pediatr Gastroenterol Nutr 2019; 69: 200-5. [PubMed][CrossRef]

5. Elli L, Roncoroni L, Bardella MT. Non-celiac gluten sensitivity: Time for sifting the grain. World J Gastroenterol 2015; 21: 8221-6. [PubMed][CrossRef]

6. De Giorgio R, Volta U, Gibson PR. Sensitivity to wheat, gluten and FODMAPs in IBS: facts or fiction? 
Gut 2016; 65: 169-78. [PubMed][CrossRef]

7. Norsk barnelegeforening. Pediatriveiledere. Generell veileder. 5.13 Cøliaki. Revidert 2015.

https://www.helsebiblioteket.no/pediatriveiledere?menuitemkeylev1 $=5962 \&$ menuitemkeylev2 $=5967$ \&key=144516 Lest 14.1.2020.

8. Al-Toma A, Volta U, Auricchio R et al. European Society for the Study of Coeliac Disease (ESsCD) guideline for coeliac disease and other gluten-related disorders. United European Gastroenterol J 2019; 7: 583-613. [PubMed][CrossRef]

9. Lov om folketrygd (folketrygdeloven) LOV-1997-02-28-19. § 6-3. Grunnstønad.

https://lovdata.no/dokument/NL/lov/1997-02-28-19/KAPITTEL_5-2\#KAPITTEL_5-2 Lest 14.1.2020.

Publisert: 20. januar 2020. Tidsskr Nor Legeforen. DOI:10.4045/tidsskr.19.0777

(C) Tidsskrift for Den norske legeforening 2020. Lastet ned fra tidsskriftet.no 